\title{
The Effect of Management Compensation and Debt Requirements on Earnings Management Concerning The Impairment of Assets
}

History:Received date 13 Dec 2014Revised date 15 Oct 2015Accepted date 24 Nov 2015

\author{
LLOYD KEVIN CO ABRIGO \& RODIEL C. FERRER*
}

Accounting Department of De La Salle University, 2401 Taft Ave, Malate, Manila, Philippines

${ }^{\star}$ Corresponding Author, E mail address: rodiel.ferrer@dlsu.edu.ph

\begin{abstract}
This study determines the relationship between the impairment decision, as well as its magnitude, and two earnings management motivations, namely increasing management compensation, and meeting debt requirements. The computation of value in use in the impairment loss is subject to management's estimate of future cash flows and choice of discount rate, which tolerates earnings management. Certain indicators and financial ratios were used to depict the effect of the two motives on impairment. In addition to this, the effect of firm size on impairment was also analyzed. The data were obtained from the OSIRIS database and the SEC form 17-A of the respective companies, as well as from telephone interviews and surveys. Probit regression was used to analyze the effect of the different motives to the impairment decision while multiple linear regression was used for the impairment magnitude. The findings show that publicly listed companies in the Philippines are engaging in "income smoothing" and "big bath" accounting with the use of impairment. Results also indicate that most "big bath" happens during periods where changes in the company's executive officers occur. Lastly, there is also evidence that financially strong companies are deferring their impairment recognition to obtain a lower cost of financing.

Keywords:Management Compensation; Debt Requirements; Earnings Management Concerning; The Impairment of Assets.
\end{abstract}

\section{INTRODUCTION}

During the past few years, the Philippines experienced a handful of companies that were alleged to have committed accounting fraud. Examples of these companies include the BW Resources Corporation, Urban Bank and Legacy Group. Some of these companies were proven guilty that resulted to many of their top management to be imprisoned. However, by the time the top officials and other people responsible for the fraud got convicted, they had already caused serious problem and damage to their employees, investors and the public, in the form of lost pensions and lost funds, as well as the rapid and significant decline in stock price.

Although there are many ways to perpetuate fraud, one of the easiest and most common ways is through the use of accounting discretions. In the past, there are numerous accounting flexibility that gives an opportunity to manage corporate earnings. Fortunately, as a result of the many whistle blowers that revealed companies taking advantage of these accounting discretions, accounting regulatory bodies amended the standard with the intention of eliminating the capacity of management to manage earnings. Therefore, there is less management subjec-tivity in the current standard than before. 
Unfortunately, despite of the minimal subjectivity provided by the standard, some companies are still able to take advantage of it to manage their earnings. Although some people may say its effect in the financial statements is minimal, yet the reward of these "small" adjustments is large. One of the easiest, cheapest, and popular ways of earnings management through the use of accounting discretion is the impairment decision. Consequently, many theoretical and empirical studies have been conducted on the said field from different countries. However, despite the popularity of the topic to researchers, no study has yet been conducted as to the factors that contribute to the impairment decision in the Philippines.

This study sought to validate whether the factors that signal impairment in the US and UK market also apply in the Philippine setting. Since impairment is recognized when the carrying amount of the asset exceeds the higher between fair value less cost to sell and its value in use, management may prevent the recognition of impairment by increasing the estimate on future cash flow or by using a low discount rate, in order to achieve the specific agenda. This prevents additional expenses from being recognized in the company's income statement, thus resulting to an overstated net income for the period. As a result, numerous theoretical and empirical studies had been conducted regarding the possibility of earnings management with the use of impairment. However, no study has yet been conducted as to whether these factors apply in the Philippine setting. Hence, this research determined what earnings management factors affect the impairment of tangible and intangible assets on Philippine's publicly listed companies for the years 2005 until 2009.

This study has three main objectives relating to the impairment of tangible and intangible assets. The first one is to provide evidence on whether companies in the Philippines are managing their earnings. Next is to determine the different factors that affect the said impairment, other than those included in the impairment computation. Finally, the last objective is to determine the relationship of management compensation, management change, and company's debt leverage to the impairment of tangible and intangible assets.

The results of this study would help a vast number of stakeholders determine the practice of companies with regard to the impairment recognition. For the board of directors, this study would let them know whether management tends to defer impairment when there are bonuses or other compensation tied up to the company's net income. The financial institutions, on the other hand, would know whether companies tend to use impairment recognition in order to improve their financial ratios and decrease their cost of debt. The government, in contrast, would determine the extent of companies presenting fraudulent financial information.

For the accounting regulatory bodies, this study would let them know how companies are actually applying the rules and standards that they have est ablished. This study would also alert investors to be very cautious of the tendency for management to manipulate the financial information when provided with compensation that is tied up with the company's reported earnings. Finally, the general public would learn to detect companies that show signs of earnings management using impairment and consequently, avoid investing their funds with the said companies.

This study covered all the listed companies in the Philippines Stock Exchange for the years 2005 until 2009. However, companies whose stocks are inactive in the stock market for at least one year were eliminated from the study. Companies that have incomplete data for some of the variables in 
the study were also totally excluded, so as to have a balanced panel. This study used primary and secondary data. The secondary data, which comprise of financial ratios, were obtained from the Osiris database and the SEC Form 17-A of the respective companies in the Philippine Stock Exchange library.

The primary data, in contrast, which depict the management compensation motive, were gathered via telephone interview and electronic survey. Nonetheless, for companies that do not want to participate in the study, the needed data were analyzed from their SEC Form 17-A. However, this was only used as a last resort because the primary data provided more credibility, as well as accountability on the part of the respondents and because of time constraints to read all the forms. Since the dependent variable, impairment probability, is a dichotomous variable, it necessitates the use of a qualitative regression model. However, in order to make the most efficient use of the gathered data, quantitative regression model was also used to analyze the degree to which the different predictor variables affect the magnitude of impairment.

This study contains some limitations that should be remembered in the implication of its results. First, it is important to note that the study is limited only to the extent of the impairment for tangible and intangible assets. Second, the research excluded the financial statements issued by companies that have a reporting period of less than 12 months, such as those issued by companies that changed from their respective fiscal year into calendar year. Lastly, the samples that contain no impairment were removed from the multiple linear regression analysis. This arose out of the necessity to log the impairment magnitude (dependent variable) in order to make the amounts comparable with the independent variables.

\section{LITERATURE REVIEW AND HYPOTHESES DEVELOPMENT}

\section{THEORETICAL FRAMEWORK}

The different theories underlying this study are market economy theory, prospect theory, agency theory, and the positive accounting theory. Market economy theory explained the cause of impairment while the other theories addressed the earnings mana-gement motives.

\section{MARKET ECONOMY THEORY}

The market economy theory explains that the value of an asset is realized by future trades or events. In other words, it is determined by the market economy of a country. According to Sun and $\mathrm{Xu}$ (2010), the market economy has two distinct characteristics: freedom and uncertainty. They explained fr eedom as advocating free competition among enterprise. As a result of this competition, Lazonick (2003) added that all the participants will be able to maximize their own benefits. On the other hand, Sun and Xu (2010) discussed uncertainty as an adjustment by the market economy itself. They explained that the future trades or events happening in the market economy will definitely bring uncertain economic benefits for the enterprise. Hence, it is highly probable that the future economic benefit that will flow to the entity will be lower than the book value of the asset, thus, asset impairment occurs. As a result, the essential characteristics of the market economy contribute to the change in the value of the asset.

\section{AGENCY THEORY}

Agency theory explains that in order to address the potential lack of alignment in the goals, preferences, and actions between managers and shareholders, the company should tie the compensation of managers with those of shareholders through ownership or compensation (Kleiman, 2006). This 
involves giving stock options and bonuses to managers that are tied with the company's stock price. Shapiro (2005) provided empirical evidence that as a result of the strong financial alignment between the $\mathrm{CEO}$ and shareholders, CEOs make decisions that increase the company's net income or the market value of its share. As such, management compensation provides a particularly strong motivation for the CEO and other top management to manipulate the earnings of the company, in order to increase their financial well being.

\section{POSITIVE ACCOUNTING THEORY}

Positive accounting theory assumes that parties (managers, regulators, and the com-pany itself) are behaving opportunistically, that is, the different parties are acting based on their own self interest or for the increase of their own wealth (Watts and Zimmerman, 1990). Therefore, Watts and Zimmerman (1990) explained that accounting choices are made in terms of individual objectives and the effects of the accounting methods in the achievement of those objectives. Positive accounting theory has three hypotheses, namely bonus plan, debt covenant, and political cost hypotheses. The bonus plan hypothesis is essentially the same as the agency theory while the debt covenant hypothesis explains that the higher the firm's debt to equity ratio, the more likely managers will use accounting methods that will increase the income and prevent the company from violating any debt covenants (Watts and Zimmerman, 1990). Lastly, the political cost hypothesis, as discussed by Watts and Zimmerman (1990), indicates that large companies tend to recognize more impairment in order to decrease their net income and avoid being in the "public eye." This would prevent the firm from incurring additional expenses that may be imposed by external groups upon seeing the company's profitability, such as demand for increase in wages from labor unions and increase in required corporate social responsibility from the government.

\section{OPERATIONAL FRAMEWORK}

Figure 1 shows the operational framework used in the study. The different earnings management motives, which were discussed in the succeeding sections and the size of each company, constitute the predictor variables while the impairment probability and magnitude comprise the dependent variables. The different financial ratios used to proxy each factor are also shown. Because a company that wanted to increase its net in come, in order to reach a particular target, would make use of all available means or accounting flexibility to reach it, it is assumed that the earnings management motives would have the same effect on the impairment of both tangible and intangible assets. Therefore, the analysis was consolidated for both types of impairment.

\section{ASSET IMPAIRMENT}

Impairment is recognized when the carrying amount of the asset exceeds its recoverable amount. The recoverable amount is measured as the higher between the fair value less cost to sell of the asset and its value in use. The issue now arises in the subjectivity of the cost to sell and computation for value in use. Since cost to sell is oftentimes relatively immaterial, there is less subjectivity involved in this measurement. However, value in use is computed primarily on management estimate. Value in use is the present value of expected future cash flows arising from the use of the asset discounted using the discount rate applicable to assets of similar risk. The controversy here is that management may prevent the recognition of impairment by increasing the estimate on future cash flow or by using a low discount rate in order to achieve their agenda. These prevent additional expenses from 
being recognized in the company's income statement, resulting to an overstated net income for the period.

Since impairment occurs as a result of the changing market conditions that rendered the assets' recoverable amount less than its book value, the more assets a company has, the more prone it is to impairment. As such, there is a need to measure the relation of a firm's assets with the impairment decision. According to Lamm-Tennant and Rollins (1994), there are three possible proxies for a firm's size: total assets, total equity, and total revenue. Total assets, obviously, can be used to proxy the firm's size because the size of a firm is largely determined by the amount of asset it owns. In contrast, Liu and Rhee (2003) explained that total equity shows the amount of assets "genuinely owned" by the firm. Since the company is mandated to pay its debt at all cost or be forced to bankruptcy, the portion of a company's assets financed by debt can be viewed as a form of "operating lease." The company pays "rent" for those assets in the form of interest payments and the company is also required to "return" it in the form of principal payment. Lastly, total revenue can also be used to proxy for the firm's size because larger firms tend to have more revenue, since they have more assets to use in profitable operations. Although most researches use total assets to proxy a firm's size, Lamm-Tennant and Rollins (1994) provide empirical evidence that either of the three can be used. Perhaps, the only reason why a total asset is the most frequently used proxy is because most people regard assets as the only measure for a firm's size.

\section{INCOME SMOOTHING}

Income smoothing is explained by Trueman and Titman (1988) as the use of accounting techniques to level out net income fluctuations from one period to the next. Tucker and Zarowin (2006) explained that in income smoothing, the series of reported earnings would have the same average as the series of actual economic incomes, but with lower variability. It is important to know that income smoothing is different from deliberate misstatements of financial values, which would constitute outright fraud. Rather, income smoothing takes advantage on the flexibility provided in the interpretation of GAAP.

Two primary motivations to income smoothing is meeting the analysts' forecast and maintaining debt requirements. According to Athanasakou, Strong, and Walker (2010), companies generally indulge in this practice because investors are willing to pay a premium for stocks with steady and predictable earnings' streams, compared to stocks whose earnings are subject to wild fluctuations. Beatty and Weber (2003) indicated that companies also engage in this practice in order to obtain a cheaper cost of borrowing. According to Chong (2006), income smoothing is not unethical if management would use real smoothing techniques like hedging instruments; but it becomes unethical if management would use accounting discretion to smooth the earnings or engages in the many "forms" of improper timing recognition. Nelson, Elliott, and Tarpley (2001) gave evidence that management try to "flatten" their net income using the impairment decision, in order to meet the forecast or earnings' target. They found that management recognize impairment when their actual income is above the expected and defer the recognition when their actual income is below expected income. This study focused on determining the factors that would signal income smoothing with the use of impairment decision.

\section{"BIG BATH" ACCOUNTING}

Big bath accounting is the strategy 
of manipulating a company's reported income to make poor results look even worse. This is often applied when the company suffered a tremendous loss during the year (Siggelkow and Zuelch, 2010). Kirchenheiter and Melumad (2001) explained that management maximizes the company's loss by expensing the accumulated unrecognized impairment loss that resulted from income smoothing. This would result in a one-time big loss or a "big bath." They stated that the reason for this practice is because it will enable the management to reach the analyst's forecast easily on the succeeding years, since there would be no more impairment loss to recognize. Furthermore, according to Siggelkow and Zuelch (2010), management perceives that increasing the tremendous loss that the company had already incurred for the year would have little impact on the company and would not affect the company's reputation. Impairment decision is commonly used by many companies in the United States to smooth its income and as a 'big bath'. Although it is quite inconceivable for a company to use b oth income smoothing and big bath accounting method, Kirchenheiter and Melumad (2001) provided evidence of companies employing both income smoothing and big bath accounting.

When companies engage in "big bath" accounting, their management or CEO often has an instant excuse to tell the public. According to Selling (2007), Citigroup, Inc wrote-off 8-10 billion dollars on November, 2007 and blames it all to events that took place in October. On the other hand, Selling (2007) also mentioned that General Motors (GM) Corporation reported an allowance of 39 million dollars and then its management declared that GM continues to believe its long term financial outlook. This is obviously because GM anticipates having higher profits in the future, as a result of having recognized some of its future expenses.

\section{EARNINGS MANAGEMENT MOTIVES}

Nelson et al. (2001) indicated two major earnings management motivations, which are increasing management compensation and meeting debt requirement.

\section{MANAGEMENT COMPENSATION}

Prior researches show that impairment decision is used by some management to increase their compensation. As a result of the increased awareness of the people regarding agency problem, many companies devise compensation schemes that link the managers' compensation to the well being of the enterprise. This somehow solves the agency problem; however, it provides management with an incentive to defer the recognition of impairment, so as to increase the company's net income and their compensation.

Many studies provided empirical evidence of a significant relation between management compensation and management change to impairment. The research of Mergenthaler, Rajgopal, and Srinivasan (2009) provided evidence of a $6 \%$ and $10 \%$ bonus cut in the compensation, as well as a $3 \%$ and $5 \%$ unconditional probability of dismissal for the chief financial officer (CFO) and chief executive officer (CEO) respectively, as a result of failing to meet the analysts' forecast twice. Another study by Guan, Wright, and Shannon (2005) found evidence that less or no impairment is recognized during the last full year of an outgoing CEO. On the other hand, a similar study conducted by Wells (2002) pointed out that a huge impairment or "a big bath" is deliberately recognized in the transition year by the incoming CEO. Cheng and Warfield (2005) supplied evidence that impairment decision is used by managers with high equity incentive to increase the value of their shares. They found out that managers want to sell their shares at the earliest time possible in order to diversify the risk, as a result of the 
volatility of stock price. This gives the managers an incentive to defer impairment to increase shortterm stock prices. Then the hypothesis is formulated as follows:

$H_{0}$ : Executive compensation and management change have no significant impact on impairment decision and magnitude.

$\mathrm{H}_{1}$ : Executive compensation and management change have significant impact on impairment decision and magnitude.

\section{DEBT REQUIREMENT}

The last major incentive for companies to manage their earnings is to maintain the requirements of a debt coven ant. This is because breaking a provision in a debt covenant would make most debts demandable immediately, which will cause most companies to suffer significant liquidity problems. Beatty and Weber (2003) provided evidence that companies having an existing debt contract or bank loan tend to have less or no impairment loss, when there are provisions that tie the variable interest rate to the performance of the company or restrict dividend payment subject to certain performance measures.

Beneish and Press (1993) depicted evidence that lenders of firms under technical default have an increase control over the firm's activities and exercise various contractual rights, such as imposing refinancing and restructuring costs on violators. They explained that refinancing costs arise because most lenders raise the interest rates on loans following violation. The same study also furnished proof of companies losing their profitable investments by modifying their operations, in order to meet the lender's repayment demands. Moreover, it provided evidence that violations are less costly for firms that can obtain a waiver than for those that cannot. However, the waivers are costly, since lenders extract fees and concessions in exchange for granting them (Beneish and Press, 1993). Hence, breaking a debt provision can result in the incurrence of a substantial amount of cost. Therefore, most companies would choose to manage their earnings in order to avoid reaching technical default. Then the hypothesis is formulated as follows:

$H_{0}$ : Debt to total assets ratio has no significant impact on impairment decision and magnitude. $\mathrm{H}_{2}$ : Debt to total assets ratio has significant impact on impairment decision and magnitude.

\section{FIRM SIZE}

In some previous studies (e.g. Chunguang, 2006; Xin, 2008; Fang-fei, 2008) found that some of the characteristics of the company have effect on earnings management, particularly in the form of asset impairment. Based on these arguments, the last hypothesis is formulated as follows:

$H_{0}$ : Total assets, total revenue, and total equity have no significant impact on impairment decision and magnitude.

$H_{3}$ : Total assets, total revenue, and total equity have significant impact on impairment decision and magnitude.

\section{METHOD RESEARCH DESIGN}

This study is considered a causal and correlational research, which aimed to determine the relationship of the different earnings management factors to the impairment decision. It is both a quantitative and qualitative study that measured the effects of the earnings management motives (independent variables) to the impairment probability and impairment magnitude (dependent variables). Being a causal research, it determined whether the impairment decision is caused by the variables that indicate earnings management. As a correlational research, the study sought to know the 
relationship of the earnings management motivations to the impairment decision. Besides knowing the relationship, this study also obtained an estimate of the possible impact that each of the independent variable had on the impairment loss. The earnings management variables would reflect the different motives that may cause the comp any to use the impairment decision to manage their earnings.

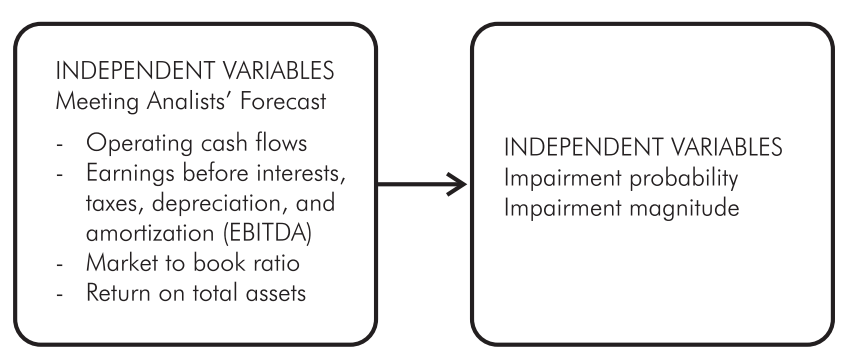

FIGURE 1. DIAGRAM OF THE OPERATIONAL FRAMEWORK

\section{POPULATION AND RESPONDENTS}

The population of the study is comprised of all the listed companies in the Philippines Stock Exchange for the years 2005-2009. This study excluded companies that have inactive stocks, as well as those companies that lack some data on particular variables. Companies are classified to have an inactive stock if the market value of its shares did not fluctuate for at least one whole year.

The year 2005 is the starting period because it is at this year when most companies initially adapted the International Financial Reporting Standards (IFRS). This study covered companies from the different sectors of the economy namely, financial sector, industrial sector, holding firms, property sector, service sector and mining and oil sector. Overall, there are 251 listed companies in the Philippine Stock Exchange.

\section{METHODS OF DATA ANALYSIS}

This study used two statistical tools to analyze the data namely, probit regression model and multiple linear regression model. However, since the study used panel data, the appropriate panel analysis was also executed. Both the probit regression and the multiple linear regression addressed all the objectives and used the same independent variables. However, differences arise in the tested hypothesis. The probit regression tested the effect of the predictor variables on the probability of recognizing an impairment loss. On the other hand, the multiple linear regressions tested the effect of the predictor variables on the magnitude of impairment loss recognized.

\section{PROBIT REGRESSION MODEL}

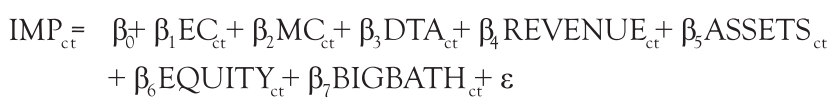

(1)

In the above equation, the predicted variable, $\mathrm{IMP}_{\mathrm{it}}$, is a binary variable that takes the value of 1 , granted that company recognizes an impairment loss in period $t$ and 0 if it did not while the remaining variables are all predictor variables. $\mathrm{OCF}_{c t}$ represents the operating cash flows divided by the total assets while EBITDA ${ }_{c t}$ is the earnings before interest, taxes, depreciation, and amortization divided by total assets. $\mathrm{MBR}_{\mathrm{ct}}$ stands for company c's market to book ratio in period t. $\mathrm{EC}_{\mathrm{ct}}$ and $\mathrm{MC}_{\mathrm{ct}}$, which are both indicator variables, are used to signify whether the company provides bonuses that are affected by impairment loss and whether a change in top management occurred in a given year, respectively. DTA ${ }_{c t}$ is the company's debt to assets ratio while ROA ${ }_{\text {ct }}$ depicts the company's return on total assets ratio. Parallel to the study of Lamm-Tennant and Rollins (1994), the total revenues, total assets, and stockholders' equity were used to proxy a firm's size. REVENUE ct $_{\text {was mea- }}$ sured as the log of the total revenue. ASSETS ${ }_{c t}$ on the other hand, was measured as the log of the total 
assets. Lastly, EQUITY ${ }_{\mathrm{ct}}$ was measured as the log of the company's stockholders' equity. Similar to the study of Siggelkow and Zuelch (2010), the earnings management indicator was used to proxy for big bath accounting. This indicator was calculated using the following formula:

Earnings management indicator $=\left(\right.$ EBITDA $_{\mathrm{ct}} /$ Total assets $\left._{\mathrm{ct}}\right)$ $\left(\right.$ EBT $_{c, t 11}$ Total assets $_{c, t-1}$ )

(2)

BIGBATH $_{\text {ct }}$ proxies for big bath accounting and equals the earnings management indicator if this falls below zero and 0 otherwise.

Multiple Linear Regression Model $\mathrm{IMM}_{\mathrm{ct}}=\alpha_{0}+\alpha_{1} \mathrm{OC}_{\mathrm{ct}}+\alpha_{2} \mathrm{EBITDA}_{\mathrm{ct}}+\alpha_{3} \mathrm{MBR}_{\mathrm{ct}}+\alpha_{4} \mathrm{EC}_{\mathrm{ct}}+\alpha_{5} \mathrm{MC}_{\mathrm{ct}}$ $+\alpha_{6}$ DTA $_{c t}+\alpha_{7}$ ROA $_{a t}+\alpha_{8}$ REVENUE $_{a t}+\alpha_{9}$ ASSETS $_{c t}^{+} \alpha_{10}$ EQUITY $_{\mathrm{ct}}$ $+\alpha_{11} \mathrm{INCSMOOTH}_{\mathrm{tt}}+\alpha_{12} \mathrm{BIGBATH}_{\mathrm{ct}^{+}}+\varepsilon$

(3)

The multiple linear regression model contains essentially the same variables as the probit regression model, except for the endogenous variable. The dependent variable, IMM $\mathrm{ct}_{\mathrm{ct}}$ signifies the degree of impairment or the actual amount of impairment recognized by the company in a given year, rather than being simply a dichotomous variable, as in the probit regression.

\section{PANEL ANALYSIS}

Since panel data was used in the study, the appropriate panel analysis was conducted. Panel analysis is composed of a series of steps to determine, which among three models namely, the ordinary least squares (OLS), fixed effects model (FEM) or least squares dummy variables (LSDV), and the random effects model (REM) was most appropriate for the research. The test of overall significance of dummies was conducted to find out which among the three variations of FEM, LSDV1, LSDV2 and LSDV3, would be most proper to represent FEM. Afterwards, Wald Test was con- ducted to decide whether the chosen LSDV model or OLS would be the better model. The said test was performed manually using certain data from both the OLS and the LSDV model, as well as the formula below.

In the said test, if the f-statistics is greater than the critical f-value, then FEM is presumed to be the better model. Otherwise, OLS would be the preferred model. Since the result, as shown below, displays OLS as the better model, Breusch-Pagan lagrangian multiplier test was subsequently administered to compare OLS and REM. If the p-value in the said test is less than 0.05, REM would be the accepted model, otherwise, OLS would be the superior model. The result of the panel analysis as depicted below, shows OLS as the most appropriate model for the data. According to Gujarati (2004), pooled regression (or OLS) allows greater flexibility in modeling differences in sample specific behavior. Although it does not account for the cross sectional relationships, sometimes no significant relationships among the cross-sectional observations exist, as in the case of this study. In addition, in terms of parsimony, it is always easier to analyze and understand the results of a more basic model. As such, the OLS model or the naive model is used in the study.

Wald Test

$$
F=\frac{\left[\left(\text { RSSR }_{R}-(\text { RSSUR })\right] / m\right.}{\left(\text { RSSUR }^{\prime} / \mathrm{D}_{f}\right.}
$$

(4)

$$
\begin{aligned}
& \begin{array}{l}
\text { Where, } \\
\text { RSSUR = }
\end{array} \\
& \begin{array}{ll} 
& \text { Pooled Regression Model/Ordinary } \\
\text { RSS }= & \text { Fixed Effects Model } \\
M \quad= & \# \text { of parameters } \\
\text { Df }= & \# \text { of observations }-\# \text { of parameters } \\
& \text { (degree of freedom lost) }
\end{array}
\end{aligned}
$$




\section{RESULTS AND DISCUSSION DESCRIPTIVE STATISTICS}

Some of the variables are "log," in order to have more comparable values with the other independent variable. These variables are LOGIMM, LOGASSETS, LOGREVENUE, and LOGEQUITY. IMM, which is a dependent variable, is the gross impairment actually recognized by the company. As will be shown in the following section, the average of IMM variable is tremendously large, compared to all the independent variables. Hence, in order to have a more meaningful result, the IMM variable was "log" with the resultant shown in the LOGIMM variable.

This resulted to all the firm years that have no or zero impairment getting removed. Hence, the 179 observations in LOGIMM represent firm years that contained a recorded impairment loss on the tangible or intangible assets. The LOGASSETS, LOGREVENUE, and LOGEQUITY, as discussed in the methodo-logy, are the log of assets, revenue and equity, respectively. There is the necessity to $\log$ these values because of their tremendous size, which can distort the results. The firm years containing no or zero revenue are removed, resulting to 768 observations for the LOGREVENUE variable. The same thing happened to LOGEQUITY, where the firm years containing zero or negative shareholders' equity (deficit) are removed, resulting to 786 observations for the said variable.

About $57 \%$ of the companies recognized an impairment loss within the period 2005 until 2009. However, if counted based on firm years, there are only about $22 \%$ of the total firm years that contain impairment. This percentage is actually the mean of the impairment probability variable because the only inputs for this variable are 0 and 1 . The average impairment loss based on firm years, including the ones that did not contain any impairment totaled $\mathrm{P}$ $44,000,000$. The smallest input for the IMM variable is logically 0 because of firm years that contain no impairment while the largest amount is P 4,760,000,000. LOGIMM, in contrast to IMM, has an average of 16.92 and a maximum value of 22.28. This clearly shows the huge difference in the amount of IMM, as a result of getting log. The minimum value of 9.62 represents the log of the smallest impairment loss recognized in one firmyear.

This section discusses the descriptive statistics for the independ ent variables. The executive compensation, which is composed of only O's and 1 's values, has an average of 0.45 . On the contrary, the management change variable, which is also a dummy variable, has an average of 0.28.

TABEL 1.DESCRIPTIVE STATISTICS FOR THE SAMPLE FIRMS

\begin{tabular}{llllll}
\hline Variable & Obs & Mean & Std. Dev. & Min & Max \\
\hline IMM & 835 & $4.40 \mathrm{e}+07$ & $2.88 \mathrm{e}+08$ & 0 & $4.76 \mathrm{e}+09$ \\
LOGIMM & 179 & 16.91584 & 2.448717 & 9.615806 & 22.28267 \\
IMP & 835 & .2143713 & .4106314 & 0 & 1 \\
EC & 835 & .4538922 & .4981679 & 0 & 1 \\
MC & 835 & .2838323 & .4511267 & 0 & 1 \\
DTA & 835 & .5937114 & .9223171 & 0 & 8.6369 \\
BIGBATH & 835 & -1.002845 & 15.17324 & -302.1571 & 0 \\
LOGASSETS & 835 & 15.16456 & 2.467275 & 4.94876 & 20.57482 \\
LOGREVENUE & 768 & 13.5215 & 3.306133 & 0 & 19.41175 \\
LOGEQUITY & 786 & 14.55256 & 2.176831 & 3.465736 & 19.18063 \\
\hline
\end{tabular}

The debt to assets ratio has an average of 0.59 with the smallest amount at 0 , indicating no debt, and the highest amount at 8.64. The debt to asset ratios that are higher than 1 , especially the 8.64 , shows firm years where the total liabilities of the firm are more than its total assets, as in the case when the firm has a negative shareholders' equity. BIGBATH provided an average value of -1.00 , which indicates that despite the lowest data under BIGBATH depicting a value of -302.16 , majority of the amounts are close to -1.00 . Finally, the LOGASSETS, LOGREVENUE and LOGEQUITY 
TABLE 2.THE PAIRWISE CORRELATION COEFFICIENTS OF THE VARIABLES ANALYZED FOR PROBIT REGRESSION

\begin{tabular}{|c|c|c|c|c|c|c|c|c|}
\hline & IMP & EC & $M C$ & DTA & $B I G B \sim H$ & $L O G A \sim S$ & $L O G R \sim E$ & LOGE $\sim Y$ \\
\hline IMP & 1.0000 & & & & & & & \\
\hline $\mathrm{EC}$ & 0.0447 & 1.0000 & & & & & & \\
\hline$M C$ & 0.0199 & 0.1519 & 1.0000 & & & & & \\
\hline DTA & 0.1128 & 0.2930 & 0.1032 & 1.0000 & & & & \\
\hline BIGBATH & -0.0453 & -0.0823 & -0.0524 & -0.1813 & 1.0000 & & & \\
\hline LOGASSETS & 0.1900 & 0.3767 & 0.1871 & 0.5270 & -0.1553 & 1.0000 & & \\
\hline LOGREVENUE 0.1194 & 0.3972 & 0.1819 & 0.4603 & -0.2269 & 0.7832 & 1.0000 & & \\
\hline LOGEQUITY & 0.1774 & 0.3292 & 0.1832 & 0.2327 & -0.1288 & 0.9315 & 0.7556 & 1.0000 \\
\hline
\end{tabular}

TABLE 3.THE PAIRWISE CORRELATION COEFFICIENTS OF THE VARIABLES ANALYZED FOR MULTIPLE LINEAR REGRESSION

\begin{tabular}{|c|c|c|c|c|c|c|c|}
\hline & IMM & LOGIMM & IMP EC & $M C$ & DTA & $B I G B \sim H L O G A \sim S$ & $L O G R \sim E \quad L O G E \sim Y$ \\
\hline IMM & 1.0000 & & & & & & \\
\hline LOGIMM & 0.5679 & 1.0000 & & & & & \\
\hline IMP & . & & & & & & \\
\hline $\mathrm{EC}$ & 0.0624 & 0.1515 & 1.0000 & & & & \\
\hline$M C$ & 0.2132 & 0.2567 & 0.1234 & 1.0000 & & & \\
\hline DTA & 0.1632 & 0.1631 & 0.1953 & 0.1639 & 1.0000 & & \\
\hline BIGBATH & -0.1578 & -0.1503 & -0.1163 & -0.1726 & -0.2224 & 1.0000 & \\
\hline LOGASSETS & 0.3570 & 0.5347 & 0.3611 & 0.2368 & 0.5688 & $0.0720 \quad 1.0000$ & \\
\hline LOGREVENUE & 0.2841 & 0.3896 & 0.3533 & 0.1278 & 0.3846 & $0.0108 \quad 0.7566$ & 1.0000 \\
\hline LOGEQUITY & 0.3639 & 0.5584 & 0.3639 & 0.2193 & 0.2862 & $0.0777 \quad 0.9442$ & 0.75861 .0000 \\
\hline
\end{tabular}

have an average of $15.16,13.52$ and 14.55 , respectively.

\section{CORRELATION ANALYSIS}

Correlation analysis was done separately for probit and multiple linear regression because STATA removed all the results for the IMP variable, which is the dependent variable for probit regression. This is actually shown in the correlation analysis for multiple linear regressions (the second correlation table). The treatment of STATA may actually be attributed to the possible effect of the LOGIMM variable to the IMP variable. Recall that the IMP variable has the value of 1 when there is impairment and 0 when none. However, since the $\log$ of IMM removed all the observations with a zero IMM (no impairment loss), this means that all the remaining values left for IMP are 1's. As a result, Stata removed the IMP variable because it has no correlation with any of the other variables. This inference was actually proven on the first correlation table where the same independent variables are used, but the dependent variable for multiple linear regressions, LOGIMM, is removed. The IMM, which is the actual impairment, was also removed in the correlation table for probit regression because it is only relevant in relation to LOGIMM.

Many of the independent variables that were used in the probit regression exhibited an insignificant correlation with each other and the dependent variable, although some did show significant relation with the other independent variables. The earnings management indicator and big bath accounting indicator showed a negative correlation with impairment probability while the others exhibited positive correlation. However, judging from their coefficients, all of the independent variables signified a weak or possibly no correlation with the impairment probability variable, since none of their coefficients exceeded 0.25. Similar to their relation with the impairment probability, both 
TABLE 4.PROBIT REGRESSION RESULTS

\begin{tabular}{|c|c|c|c|c|c|}
\hline \multicolumn{3}{|c|}{ Significant variables } & \multicolumn{3}{|c|}{ Insignificant variables } \\
\hline \multicolumn{3}{|c|}{ Predicted } & \multicolumn{3}{|c|}{ Predicted } \\
\hline Sign & Coefficient & $P$-value & $\underline{\text { Sign }}$ & Coefficien & $P$-value \\
\hline DTA & -.524499 & $0.032^{* *}$ & BIGBATH & $-\quad .0004628$ & 0.906 \\
\hline \multirow[t]{3}{*}{ LOGEQUITY } & +.1969352 & $0.000^{* * *}$ & & $\begin{array}{ll}- & -0770157\end{array}$ & 0.513 \\
\hline & & & & $+\quad-.0617672$ & 0.594 \\
\hline & & & LOGREVENUE + & $+\quad-.0484953$ & 0.112 \\
\hline \multicolumn{6}{|c|}{$\begin{array}{ll}* & \text { represent variables that a re significant at } \alpha=0.10 \text {. } \\
*_{*}^{* *} & \text { represent variables that are significant at } \alpha=0.05 \text {. } \\
* * * & \text { represent variables that are significant at } \alpha=0.01\end{array}$} \\
\hline
\end{tabular}

TABLE 5.LOGIT REGRESSION RESULTS

\begin{tabular}{|c|c|c|c|c|c|}
\hline \multicolumn{2}{|c|}{ Significant variables } & \multicolumn{4}{|c|}{ Insignificant variables } \\
\hline \multicolumn{2}{|l|}{ Predicted } & \multicolumn{3}{|c|}{ Predicted } & \\
\hline Coefficient & $P$-value & Sign & Coefficient & P-value & \\
\hline-.9243478 & $0.031^{* *}$ & BIGBATH & - & .0009472 & 0.877 \\
\hline LOGEQUITY + .3481437 & $0.000^{* * *}$ & EC & - & -.1320361 & 0.520 \\
\hline LOGREVENUE $+-.08945230 .097^{*}$ & & $M C$ & + & -.0893126 & 0.654 \\
\hline $\begin{array}{ll}* & \text { represent variables that a re signi } \\
* * & \text { represent variables that are signif } \\
* * * & \text { represent variables that are signifi }\end{array}$ & $\begin{array}{l}\text { cant at } \alpha=0.10 \text {. } \\
\text { ant at } \alpha=0.05 \text {. } \\
\text { ant at } \alpha=0.01\end{array}$ & & & & \\
\hline
\end{tabular}

the big bath accounting indicator and management change depicted a weak or poor correlation in relation to all other independent variables.

The remaining independent variables exhibited some significant relation with each other. The earnings-based bonus payment indicator exhibited a moderately positive correlation with the debt to assets ratio, total assets, total revenue and total equity while the debt to assets ratio is also moderately correlated with the total assets and total revenue. Finally, the total assets, total revenue and total equity are all moderately to highly correlated with each other.

Unlike the correlations under probit regression, more variables exhibited a moderate to high degree of correlation with the predicted variable and the other exogenous variables under multiple linear regressions. The dependent variable, LOGIMM, depicted a moderately positive correlation with the gross impairment, management change, total assets, total revenue and total equity. This shows that although LOGIMM is simply the log of the gross impairment, its correlation with it is quite low. The other independent variables also exhibited some moderate to high correlation with the other independent variables. The earnings-based bonus payment and the debt to assets ratio both have a moderately positive correlation with total assets, total revenue and total equity. Lastly, similar to the results for the correlation analysis on the variables for probit regression, the total assets, total equity and total revenue are all moderately to highly correlated with each other. 


\section{PROBIT REGRESSION ANALYSIS}

The probit regression result is shown in Table 4 and logit regression result is shown in Table 5 .

\section{Big Bath Accounting Indicator (BIGBATH) with Impairment Decision as Dependent Variable}

Big bath accounting indicator conveyed a insignificant relation with the impairment decision.

This is contrary to the expectation beforehand and to the findings of Kirchenheiter and Melumad (2001), but consistent with the empirical researches of Siggelkow and Zuelch (2010) and Athanasakou et al. (2010). The apriori expectation provides a positive relation, since, as explained by Kirchenheiter and Melumad (2001), companies often engage in big bath accounting in order to recognize the accumulated deferred impairment that results from consistently having earnings that are just below the analysts' forecast. In other words, big bath accounting is the by product of income smoothing.

The resulting insignificant relation between the two variables denotes that management does not engage in "big bath" accounting with the use of the impairment decision. This may, perhaps, be the result of management's awareness of the consequences of pursuing a "big bath," such as bad publicity and forced re-statement of all prior year financial statements to correct the "mistake" by the Securities and Exchange Commission (SEC).

\section{Earnings-based Bonus Payment Indicator (EC) with} Impairment Decision as Dependent Variable

The earnings-based bonus payment indicator, otherwise called executive compen-sation indicator, showed an insignificant relation to the impairment decision. This result is in conflict with the prior expectation and the study of Beatty and Weber (2003) and Guan et al. (2005), but consistent with the findings of Siggelkow and Zuelch (2010). The previous expectation, which was based on the study of Beatty and Weber (2003), is that companies that provide bonus plans and do not exclude impairment reduce the impairment probability because management is trying to improve the reported earnings of the company, so as to obtain a higher bonus. This explanation is also in conformity with the agency theory discussed by Kleiman (2006) and Shapiro (2005).

The most compelling reason that can be attributed to this finding is that employees are often reluctant to ask for the help of their co-worker in perpetrating fraud. However, the result may also imply that the compensation scheme actually works in boosting the performance of the company and does not incite the employees to engage in earnings management.

\section{Management Change Indicator (MC) with Impair- ment Decision as Dependent Variable}

The management change indicator also exhibited an insignificant relation with the impairment decision. This result is opposed to the prior expectation and to the findings of Cheng and Warfield (2005), Wells (2002), and Guan et al. (2005), but consistent with the study of Siggelkow and Zuelch (2010) and Lamm-Tennant and Rollins (1994). It is expected that a change in the company executives would have a higher impairment probability because the new executive has the incentive to recognize all discretionary expenses, in order to get rid of them and blame the old management for the low profit during the year of change. The insignificant relation implies that the company recognizes impairment, notwith-standing whether a change in the top management occurs. However, when a change in top management occur, the amount of impairment recognized may be larger than usual. As such, the effect of management change may be clearer when the actual amount of impairment is taken into account. 
Debt to Total Assets Ratio (DTA) with Impairment Decision as Dependent Variable

The debt to total assets ratio denoted a significant positive relation with the impairment decision, as manifested by its $\mathrm{p}$-value of 0.03 , which rendered the variable significant at á equals 0.05 . This result is again in contrast to previous expectation, as well as the research of Beneish and Press (1993) and Beatty and Weber (2003). It is, however, consistent with the study of Dichev and Skinner (2001). The prior expectation is that the higher the leverage, the lower the impairment probability because management of firms approaching technical default would tend to make income increasing accounting decisions (Beneish and Press, 1993; Watts and Zimmerman, 1990). The most explicit implication of this result is that companies that already have high debt to assets ratio may already be incapable of obtaining a loan at a reasonable price; hence, they do not have an incentive to defer the recognition of impairment. On the other hand, fin ancially strong companies would defer the recognition of impairment in order to have a high net income and low debt to assets ratio. This would, in turn, decrease their perceived risk and allow them to obtain cheaper cost of debt.

Total Revenue (REVENUE) with Impairment Decision as Dependent Variable

Although the probit regression results indicated an insignificant $p$-value, the results from the logit regression displayed the total revenue as having suggestive evidence of a negative relation. The total revenue would be considered as having suggestive evidence because it may actually provide some valuable information that rendered it significant in the logit regression result. The finding, however, is inconsistent with the prior expectation and with the study of Siggelkow and Zuelch (2010) and Lamm- Tennant and Rollins (1994) while consistent with the research of Liu and Rhee (2003).

The expected relation is positive because the larger a company, the more assets it has that are prone to impairment. In addition, the political cost hypothesis also discusses that large companies tend to choose income-decreasing accounting choices in order to avoid exposure to political scrutiny (Watts and Zimmerman, 2010). Although initially intended to proxy for firm size, the total revenue can also be used to proxy the pattern exhibited by the net income because of its direct relation. As a result, the negative relationship of total revenue and the impairment decision implies suggestive evidence that companies are using the impairment decision to engage in small "big bath" accounting. According to Siggelkow and Zuelch (2010), "big bath" accounting is often practiced by recognizing impairment when the net income of the company is low so that the future earnings will be higher. It is important to emphasize that what is referred here is "small 'big bath' accounting." This is the practice of recognizing a "big bath" only to the extent where it will not raise public attention because of the extremely low earnings.

\section{Total Equity (EQUITY) with Impairment Decision as Dependent Variable}

Total equity exhibited a highly significant positive relation with the impairment decision, as displayed by its $\mathrm{p}$-value. The result is consistent with prior expectation, as well as the findings in prior researches, such as Athanasakou et al. (2010) and Liu and Rhee (2003). Kasznik and McNichols (2002), however, found no significant relation between the total equity and impairment. The significant positive relation provides evidence in support of the market economy theory, where larger firms tend to have more impairment because of changes in market condition. 


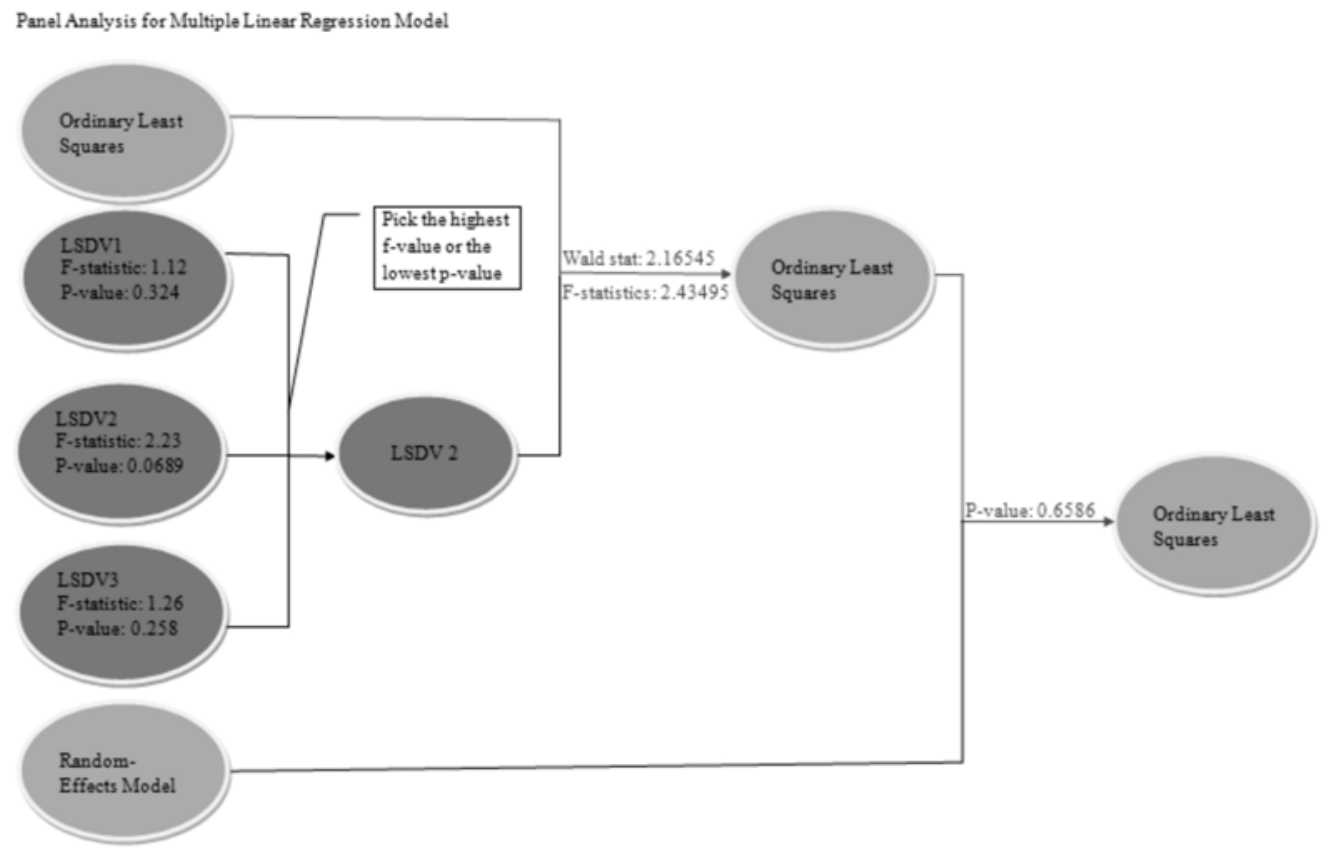

FIGURE 2. DIAGRAM OF THE PANEL ANALYSIS

TABLE 6.MULTIPLE LINEAR REGRESSION RESULTS

\begin{tabular}{|c|c|c|c|c|c|c|c|}
\hline \multicolumn{4}{|c|}{ Significant variables } & \multicolumn{4}{|c|}{ Insignificant variables } \\
\hline $\begin{array}{l}\text { Predicted } \\
\text { Sign }\end{array}$ & Coefficient & P-value & & $\begin{array}{l}\text { Predicted } \\
\text { Sign }\end{array}$ & Coefficient & P-value & \\
\hline BIGBATH & - & -.0584841 & $0.034^{* *}$ & INCSMOOTH & + & .1257443 & 0.651 \\
\hline MC & + & .6644616 & $0.057^{*}$ & $\mathrm{EC}$ & - & -.3514986 & 0.295 \\
\hline LOGEQUITY & + & .896148 & $0.000^{* * *}$ & $\begin{array}{l}\text { DTA } \\
\text { LOGREVENUE }+\end{array}$ & $\begin{array}{c}- \\
-.0592947\end{array}$ & $\begin{array}{c}-.5464387 \\
0.484\end{array}$ & 0.415 \\
\hline $\begin{array}{ll}{ }^{*} & \text { represen } \\
{ }_{* *}^{* *} & \text { represen } \\
{ }^{* * *} & \text { represent }\end{array}$ & $\begin{array}{l}\text { bles that a re } \\
\text { bles that are } \\
\text { bles that are }\end{array}$ & $\begin{array}{l}\text { significant a } \\
\text { significant at } \\
\text { significant at }\end{array}$ & $\begin{array}{l}\alpha=0.10 \\
x=0.05 \\
=0.01\end{array}$ & & & & \\
\hline
\end{tabular}

\section{Panel Analysis for Multiple Linear Regression}

The results of the panel analysis indicated that OLS or the naive model would be the appropriate model for the study. The first test that was conducted, the test of overall significance of dummies, indicated LSDV2 as having the highest f-value or the lowest p-value. Consequently, LSDV2 was the model used to represent FEM for the Wald's test. The next test, the Wald's test, was conducted to determine whether OLS or FEM is the better model for the data. The results revealed an $\mathrm{f}$ statistics of 2.17 while a critical f-value is 2.43 . Since the $\mathrm{f}$-statistics is less than the critical f-value, OLS is concluded to be the better model. Finally, the last test that was conducted, the Breusch and Pagan Lagrangian multiplier test, examined whether OLS or REM is the more appropriate model. The result revealed a p-value of 0.65 , which implies that OLS is the better model. Hence, OLS is the model used for the multiple linear regression analysis. 


\section{Multiple Linear Regression Analysis}

The Multiple Linear Regression Results is shown in Table 6. Big Bath Accounting Indicator (BIGBATH) with Impairment Magnitude as Dependent Variable

As opposed to the result in the probit regression, big bath ac counting indicator conveyed a positive relation with the impairment magnitude, as shown by its p-value of 0.03 . The coefficient of BIGBATH may mislead some readers into thinking that big bath accounting imposes a negative relation. Remember, big bath accounting indicator is composed of all the negative amounts of the earnings management indicator. Hence, an increase in the value of BIGBATH would result to a further negative value, which means that the true relation of BIGBATH to impairment magnitude is the opposite of the sign of its coefficient. This finding is in contrast to the anticipated relation, as well as to the empirical researches of Nelson et al. (2001) and LammTennant and Rollins (1994). It is, however, consistent to the findings of Kirchenheiter and Melumad (2001) and Yuan (2008).

Consistent with the result of Yuan (2008), both the management change and the big bath accounting indicator showed a consistent positive effect on the impairment. This implies that most "big bath" happens during periods where a change in top management occurs. Usually, the practice of "big bath" accounting places a company in the public's eye and creates a bad reputation. As a result, management may have decided to "chop" the recognition of the impairment, in such a way that the investors or the public would not notice its effect on net income. This implication is evidenced both by the finding of this study and the "few" accounting scandals that are heard.
Earnings-based Bonus Payment Indicator (EC) with Impairment Magnitude as Dependent Variable

The earnings-based bonus payment indicator portrayed an insignificant relation with the impairment magnitude, as shown by the insignificant $\mathrm{p}$ value. This is contrary to the apriori expectation, where having bonuses given to executives would result to less impairment (Beatty and Weber, 2003). It is also in conflict with the researches of Beatty and Weber (2003), Lamm-Tennant and Rollins (1994) and Mergenthaler et al. (2009), but consistent with the findings of Guan et al. (2005) and Siggelkow and Zuelch (2010). As in the probit analysis, the insignificant relation may be attributed to either more effective compensation plans given by the board of directors to its executive officers or the result of the many deterrents to fraud.

\section{Management Change Indicator (MC) with Impair- ment Magnitude as Dependent Variable}

The management change indicator demonstrated suggestive evidence of a significant positive relation to the impairment magnitude, as provided by its p-value of 0.06 , which is significant at á equals 0.05 . This result is consistent with the findings of Yuan (2008) and Ronen and Yaari (2008). This finding, coupled with the result of the big bath accounting indicator, implies the practice of "big bath" accounting during periods where changes in top management occur. Hence, these findings supplied evidence that most "big bath" occur when there is a change in top management.

\footnotetext{
Debt to Total Assets Ratio (DTA) with Impairment Magnitude as Dependent Variable

Contrary to the expectation beforehand, the debt to assets ratio provided no significant relation to the magnitude of impairment recognized, as portrayed by its insignificant p-value. This is consistent with the findings of Lamm-Tennant and
} 
Rollins (1994) but inconsistent wi th the result of Beatty and Weber (2003). The apriori expectation, as explained by Beatty and Weber (2003), is that companies trying to obtain a loan would tend to have smaller amounts of impairment rather than other companies. On the contrary, the implication of having a debt to assets ratio that is insignificant as to the impairment magnitude while significant with regard to the impairment decision is that companies are trying to show their "best face" forward. This means that it recognizes no impairment at all when contracting for a lower cost of borrowing or when it has any other motives tied up with debt financing. Since the cost of borrowing is largely tied up with how risky the bank sees the company, the company could actually save a lot of money in the form of decreased interest expense by showing an excellent financial values. As a result, the debt to assets ratio has no affect on the magnitude of impairment recognized by the company.

Total Revenue (REVENUE) with Impairment Magnitude as Dependent Variable

Unlike in the probit regression result, total revenue manifested no relation with regard to the impairment magnitude, as evidenced by its insignificant $p$-value. This finding is consistent with several studies, like that of Lamm-Tennant and Rollins (1994), Lee (2007) and Martinez and Reis (2010). The expected relation is positive, since total revenue was intended to proxy for firm size. According to Liu and Rhee (2003), larger firms tend to have higher amounts of revenue because of their increased market presence and market operations, which made total revenue a good proxy for firm size. The insignificant relation may have been the result of the total revenue being an income statement item. Although the total revenue was initially intended to proxy for the firm size, it can also be used to proxy the trend exhibited by the net income because it generally has a positive correlation with net income. Hence, the nature of revenue as an income statement item and the direct positive effect of revenue to net income are the causes that prevent total revenue from being an effective proxy for the firm size.

\section{Total Equity (EQUITY) with Impairment Magnitude} as Dependent Variable

The total equity indicated a highly significant positive relation with the impairment magnitude, as presented by the $p$-value of 0.000 , which is significant at á equals 0.01 . Prior researches, such as the study of Liu and Rhee (2003) and Mergenthaler et al. (2009), indicated similar results while Ronen and Yaari (2008) cited some researches indicating no relation. The positive relation between total equity and the impairment magnitude simply reinforced the apriori expectation and the notion that the larger a firm, the more impairment it is likely to recognize. This is not surprising because of the natural tendency for the value of an asset to go down, as a result of economic obsolescence and physical damage. As such, the result of this study provided further empirical evidence in support of the market economy theory.

\section{CONCLUSION}

The study investigated the presence of any significant relationship between the different motives to earnings management and the impairment decision and magnitude. Under the market economy theory, Sun and X u (2010) discussed that the freedom of competition among enterprise and the inherent uncertainty of events in the market will cause an asset to become impaired. However, management also has its own reasons for the impairment.

The practice of "big bath" accounting occurs more frequently when there is a change in the 
executive officers or top management of the company while executive bonuses have no relation to the impairment decision or its magnitude. Out of the two variables designed to test the management's personal motive, the management change indicator provided significant relation with the magnitude of impairment recognized while the executive compensation provided no relation. Yuan (2008) expresses that "big bath" accounting frequently occurs when there is a change in the top executive of the firm. The management change and the "big bath" accounting indicator showed a parallel effect on the impairment magnitude, which signify evidence in support of Yuan's (2008) claim.

Another finding of this study is that financially strong companies are deferring the recognition of impairment when it is tied up with its cost of debt. The significant positive relation of the debt to assets ratio or leverage with the impairment decision shows that financially strong companies are usually the ones deferring the recognition of impairment in order to have a smaller interest cost. This is because low debt to assets ratio is attributed to low probability of impairment. On the other hand, financially troubled companies may not expect to obtain a loan at a reasonable interest. As such, they do not have any incentive to defer the recognition of impairment, which explains why higher debt to assets ratios is accompanied with more impairment.

Since companies are not only "forced" to have a high net income in order to meet the analysts' forecast, but they are also pressured to avoid or minimize political costs, management may decide to simply "smooth" earnings. This is assuming that the true implication of the positive relation between firm size and impairment is in accordance with the political cost theory. Income smoothing will prevent the company from recognizing huge net income that may lead to political costs, but satisfy the pressures of the stockholders of meeting the analysts' forecast. As such, it is not surprising if companies nowadays are engaging in income smoothing, as indicated by many independent variables.

The findings of the study would enable the following stakeholders to determine the accounting practices of publicly listed companies with regard to impairment, in order to react accordingly. First, for Board of Directors, since most "big bath" accounting happens during the years where changes in management occur, the board of directors should ask for the joint preparation of the financial statements for the period of the last regular financial statement to the period of change. This would avoid the "blaming game," where each party accuses the other for the bad results of the company's operation during the transition year.

Since the old management has an incentive to defer impairment, so as to show that the company was very profitable during their administration while the new management would want to recognize the deferred expenses, as well as some future expenses in order to increase the company's future income, a joint preparation of the financial statements would somehow balance the two endpoints and thereby show the actual values. In addit ion, the board of directors should also compel the new management to examine or audit the last financial statements prepared by the old management one month prior to transition. This method would not only reveal whether the old management deferred impairment but it will also prevent the new management from making biased accusations regarding the accounting practice of the old management.

Second, financial institutions should require the companies applying for a loan to have their assets evaluated by an independent appraiser. This would enable the banks to find out whether the recoverable amount used by the management is significantly different from the market value of the assets. 
In which case, these may signal possible deferring of impairment. In addition, banks and other financial institutions should not become complacent with the figures reported to them by financially healthy companies because findings indicate that these companies are the ones more likely to defer the recognition of impairment. According to Davis et al. (2009), deferring impairment would increase the companies' net income and make them appear less risky than they truly are, which would decrease the company's cost of debt. Therefore, banks and other financial institutions should be skeptic in assessing the riskiness even of financially healthy firms.

Third, The government may choose to implement heavy punishments on companies that were caught to practice earnings management, in order to protect other organizations and its citizens from being deceived. These punishments may include imposing heavy fines on the company and imprisoning the people who were found guilty of such act. The heavy fines would cause the management to assess whether the benefit of taking advantage of impairment would outweigh the risk of being caught and fined, as well as the possible disruption on the company's reputation. On the other hand, imprisonment would make management think twice whether they are willing to risk their personal lives for the "benefit" of the company. Hence, imposing both penalties and imprisonment would serve to create two deterrents, one to the company and another to its management.

Fourth, The accounting regulatory body should consider the possibility of removing the value in use alternative in determining impairment, since this tolerates earning management. If the recoverable amount would be based solely on the fair value of the asset, this would somehow limit management's ability to influence the amount and timing of impairment, since impairment would be tied to the appraiser's evaluation. Therefore, management's capacity to block impairment by claiming that the value in use is higher than the fair market value would be removed. Hence, the auditors can have an objective and independent basis to check whether impairment is necessary, as well as whether the magnitude of impairment is appropriate.

Fifth, The investors should rely more on the net cash flows provided by operating activities in ascertaining the profitability of the company, rather than on the reported earnings. This is because the operating cash flows shows the operating income of the company, excluding the non-cash expenses. In addition, it is this non-cash expenses that actually provide room for earnings management. However, this does not mean that investors should ignore the company's net income, since the non-cash expenses conside red in the reported earnings, such as depreciation, amortization, and impairment loss, represent actual and legitimate expenditures of the company. As such, investors and stockholders should base the company's result of operations both on the net cash flows provided by operating activities and the net income reported in the income statement, but putting more weight on the former because of its less management subjectivity.

Sixth, for researchers, although this study provided some interesting results, it still propels several opportunities for further research, especially with regard to addressing the limitations of the study. Even if the study covered the entire Philippine's publicly listed companies, it is important to note that the research is limited only to the impairment of tangible and intangible assets. As such, the findings do not apply to other parts of the financial statements that are subject to management discretion. As a result, future researches may attempt to determine whether the primary earnings management motives also apply to other areas of the financial statements. Since the multiple linear regression model produced an r-squared of only 
$40 \%$, another area for further research is to figure out the other factors that comprise $60 \%$ of the model. These variables may be attributed to the other earnings management motives that were not covered by this study.

Finally, general public should be aware of the companies' practice of "big bath" accounting and avoid engaging in transactions with such companies alleged or proven to engage in the said practice. There is a high probability that companies engaging in earnings management are also practicing other forms of manipulations and unethical acts. As such, it would be difficult for the public to determine the "true" financial condition and stability of the said company, which puts doubt on the company's ability to continue its operations and to honor its warranties and commitments in the products and services it offers.

\section{REFERENCES}

Athanasakou, V., N. Strong and M. Walker. 2010. The market reward for achieving analyst earnings expec-tations: Does managing expectations or earnings matter? Retrieved from Social Science Research Network. (Id=1021949)

Beatty, A. and J. Weber. 2003. The effects of debt contracting on voluntary accounting method changes. The Accounting Review, 78 (1), 119-143.

Beneish, M. and E. Press. 1993. Costs of technical violation of accounting-based debt covenants. The Accounting Review, 68 (2), 233-257

Cheng, Q. and T. Warfield. 2005. Equity incentives and earnings management. Retrieved from Social Science Research Network. $(\mathrm{ld}=626848)$

Chong, G. 2006. Is income smoothing ethical? Retrieved from http:// onlinelibrary. wiley.com/doi/10.1002/jcaf.20261/pdf

Chunguang, Z. 2006. Asset Impairments and Earnings Management. Accounting Research, 3 (003), 345-357

Davis, L., B. Soo and G. Trampeter. 2008. Auditor tenure and the a bility to meet or beat earnings forecasts. Contemporary Accounting Research, 26 (2), 517-548. Retrieved from

Dichev, I. and D. Skinner. 2001. Large-sample evidence on the debt covenant hypothesis. Retrieved from http://ssrn.com/abstract $=275174$ or doi:10.2139/ssrn. 275174

Fang-fei, D. I. N. G. 2008. Empirical Research on Non-current Assets Impairment Influenced by New Chinese Accounting Standards. The Theory and Practice of Finance and Economics, 1 (015), 789811.

Gujarati, D. 2004. Basic Econometrics. New York, NY: The McGrawHills Companies.
Guan, L., C. Wright and L. Shannon. 2005. Earnings management and forced CEO dismissal. Advances in Accounting, 2161-81.

Liu, K. and S. Rhee. 2003. The effect of firm size on earnings management. Retrieved from http://www2.hawaii.edu/ fima/PDF/ Finance_Seminar/EarningsMgmt.pdf

Kirchenheiter, M., and N. Melumad. 2001. Can "big bath" and earnings smoothing co-exist as equilibrium financial reporting strategies? Journal of Accounting Research, 40 (3), 761-797.

Kleiman, R. 2006. Agency Theory. Encyclopedia of Busines $\underline{s}$. Retrieved from: http:// www.enotes.com/biz-encyclopedia/agency-theory/

Lamm-Tennant, J. And T. Rollins. 1994. Incentives for discretionary accounting practices: Ownership structure, earnings, size, and taxation. The Journal of Risk and Insurance, 61 (3), 476-491.

Lazonick, W. 2003. The theory of the market economy and the social foundations of innovative enterprise. Retrieved from: http:// eid.sagepub.com/content/24/1/9.abstract

Lee, J. 2007. Earnings management to just meet analysts' forecast. Retrieved from: http://www.kellogg.northwestern.edu/accounting/ papers/jimmy \%20lee.pdf

Martinez, A., and G. Reis. 2010. Audit firm rotation and earnings management in Brazil. Retrieved from http://papers.ssrn.com/sol3/ papers.cfm?abstract_id $=1640260$

Mergenthaler, R., S. Rajgopal and S. Srinivasan. 2009. CEO and CFO career penalties to missing quarterly analysts' forecasts. Retrieved from http://papers.ssrn.com/sol3/ papers.cfm?abstract_id $=1152421$

Nelson, M., J. Elliott and R. Tarpley. 2001. Evidence from auditors about managers' and auditors' earnings management decisions. Retrie ved from http://papers.ssrn.com/sol3/ papers.cfm?abstract_id $=294688$

Ronen, J., and V. Yaari. 2008. Earnings management. New York, NY: Springer Science+Business Media, Inc.

Rottok, K. 2010. Auditing impairment test during a recession. Retrieved from: http://findarticles.com/p/articles/mi_qa5377/is_201003/ ai_n53506420/

Selling, T. 2007. "Big Bath" Accounting at Merrill Lynch: Give me that old time conservatism. Retrieved from: http:// accountingonion.typepad.com/ theaccountingonion/2007/11/thebig-bath-ap.html

Shapiro, S. 2005. Agency Theory. Annual Review of Sociology, 31, 263 284.

Siggelkow, L. and H. Zuelch. 2010. Earnings management concerning the impairment decision: A quantitative empirical analysis of German listed companies between 2004 and 2009. Retrieved from http://papers.ssrn.com/sol3/papers.cfm?abstract_id=1709646

Suk, I. 2006. Consistency in meeting or beating earnings expectations and management earnings forecasts. ProQuest Dissertations and Theses.

Sun, S. And X. Xu. 2010. Study on the Asset Impairment Accounting. International Journal of Business and Management, 5 (6), 199-203.

Trueman, B. And S. Titman. 1988. An xxplanation for Accounting Income Smoothing. Journal of Accounting Research, 26 (3), 127139.

Tucker, J. and P. Zarowin. 2006. Does income smoothing improve earnings informativeness? The Accounting Review, 81 (1), 251-270. Retrieved from http://bear.warrington.ufl.edu/tucker/ TAR_income_smoothing.pdf

Watts, R. And J. Zimmerman. 1990. Positive Accounting Theory: A Ten 
Year Perspective. The Accounting Review, 65(1), 131-156.

Retrieved from http://faculty.etsu.edu/pointer/

wattsandzimmerman2.pdf

Xin, Z. 2008. Empirical Research on Earnings Management in the Fourth Season of China's Listed Companies with Loss. Accounting Research, 4 (004), 564-579.

Yuan, Y. 2008. Big Bath accounting fraud. Retrieved from: http:// www.moolanomy.com/ 1048/big-bath-accounting-fraud/

Zmijewski, M. And R. Hagerman. 1981. An income strategy approach to the Positive Theory of accounting standard setting/Choice. Journal of Accounting and Economics, 3 , 12 9-149. 